\title{
Some notes on the Semerap dialect of Kerinci and its historical development
}

\author{
ERNANDA
}

\begin{abstract}
This article investigates the historical development of a hitherto undescribed Kerinci variety, the Semerap dialect, from a comparative Malayic perspective. The morphophonological characteristics of Kerinci languages are unusual within the Austronesian language family. This preliminary study, therefore, pays special attention to the characteristic four-way split of the historical rootfinal ${ }^{*} \mathrm{~V}(\mathrm{C}) \#$ in Semerap lexemes: absolute, oblique, K-words, and G-words. Like other Kerinci varieties, the Semerap dialect features a type of phonological word-shape alternation, generally known as "phrasal alternation", which also impacts on its syntax. This alternation (absolute vs. oblique) is determined by the syntactic position of the root, but also by semantic factors. To gain an accurate understanding of Semerap historical development, I also call attention to nonprenasalized voiced stops (G-phonemes), which also influence the realization of the root-final ${ }^{*} \mathrm{~V}(\mathrm{C}) \#$. Finally, an argument is made to take Kerinci varieties into account for Malay historical linguistics more generally.
\end{abstract}

KEYWORDS

Sound change; morphology; phonology; Kerinci; alternation.

\section{INTRODUCTION}

Kerinci is a region in the Jambi province, Sumatra, Indonesia, consisting of three parts; North Kerinci, Central Kerinci, and South Kerinci, all located along the Barisan Mountains. Although the historical Kerinci area has in 2008 been split into Sungai Penuh City and the Kerinci Regency by the Ministry of Home Affairs, I refer to both these administrative areas as "Kerinci", as they

ERNANDA holds a PhD in Linguistics from Leiden University. She is also a former Research Associate at the Hong Kong Polytechnic University and currently an assistant professor in the Faculty of Teacher Training and Education at Universitas Jambi, Indonesia. Her research interests include phonology, morphology, and syntax, and she is currently focusing on historical linguistics, critical discourse analysis, and grammaticalization. Ernanda may be contacted at: ernanda@unja.ac.id. 
share the same language, culture, and values. Kerinci is a Malayic language belonging to the Malayo-Polynesian branch of the Austronesian language family. The most striking differences between Kerinci dialects, of which there are many, are found in the final syllable rhyme of word roots. Kerinci dialects exhibit a process of morphophonological alternation in which the word-final syllable rhyme displays two alternating forms. Throughout this article, these

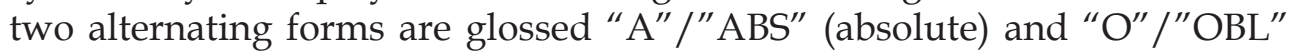
(oblique). Section 3 explains how phrasal alternation works in more detail. Conventionally, the A-form is given first in Kerinci dialects, followed by the O-form behind a slash (/). The Semerap word for 'blood', for example, is given as dahiah/dahuh.

Previous scholarship on Kerinci has mostly focused on the dialects of Sungai Penuh (SP), Pondok Tinggi (PT), and Tanjung Pauh Mudik (TPM). Researchers have investigated a number of linguistic phenomena in these Kerinci varieties. J. Isman (1958), S. Nikelas et al. (1979, 1981), J. Anwar et al. (1984), and A. Yasin (1983) made valuable contributions to the Pondok Tinggi and Semerah (SMH) dialects. The linguistic phenomenon of phrasal alternation has received considerable attention in a number of previous publications (H. Steinhauer and A.H. Usman 1978; A.H. Usman 1976, 1988; T.A. McKinnon 2011). Some years ago, D.J. Prentice and Usman (1978) have made significant contributions to the diachronic dynamics of alternation in Kerinci. More recently, Steinhauer $(2002,2018)$ has provided rich insights into the sound changes in the Sungai Penuh dialect. Data from the Tanjung Pauh Mudik dialect have also enhanced scholarly understandings of phrasal alternation (McKinnon et al. 2015; Yanti et al. 2018). Finally, the analysis of the Pondok Tinggi data has made a more general contribution to Kerinci sociolinguistics (Ernanda 2011, 2015, 2017), informing our understanding of the morphophonological and morphosyntactic functions of alternation.

The precise number of dialects spoken in Kerinci is hard to pinpoint exactly. Table 1 shows the dialect variation in the best described Kerinci varieties through the absolute-oblique opposition in G-words and K-words. These four way-split will be discussed further in Sections 3 and 5 .

\begin{tabular}{|l|l|l|l|l|l|l|}
\hline & SP & SMH & TPM & PT & SMR & Gloss \\
\hline G-ABS & daheh & daheh & dahih & dahuah & dahiah & 'blood' \\
\cline { 1 - 5 } G-OBL & dahowh & dahoh & dahiwh & dahoh & dahuh & \\
\hline K-ABS & tanah & tanah & tanah & tanah & tanah & 'land' \\
\hline K-OBL & tanoh & tanuh & tanəoh & tanoh & taneuh & \\
\cline { 1 - 5 } Sources & Usman 1976 & Yasin 1983 & McKinnon 2011 & Ernanda 2017 & this article & \\
\hline
\end{tabular}

Table 1. Dialect variation in Kerinci.

This article is the first attempt at a description of the dialect of Semerap (SMR). SMR is located in the southern part of Kerinci (Figure 1). According to an interview conducted with some SMR native speakers, the area has 
low levels of immigration, although lies approximately twelve kilometres distant from the multi-ethnic city centre of Sungai Penuh. The SMR people are proud of their mother tongue and speak it on all occasions in the village. In addition to SMR, they speak Indonesian, but only as the national language at schools. Almost half of the SMR speech community works in Malaysia (mostly as low-wage labourers). The majority of people who have stayed in SMR work as farmers in dry fields and rice-fields. The SMR people are the owners of all land, rice-fields, houses, and other assets in the SMR area. Unlike people in the city centre, SMR people never sell their property to outsiders, which explains why no immigrants live in the village. This attitude has been highly conducive to the language vitality. Massive language contact, which is happening in the city centre, has so far been avoided in SMR. As a result, their dialect is not greatly influenced by other languages. This situation is quite exceptional in comparison with other Kerinci varieties. For instance, Ernanda $(2011,2015)$ points out that the Pondok Tinggi dialect spoken in the city centre has undergone contact-induced language attrition. The dominant languages (Minangkabau, localized Indonesian) in this area have interfered with the language of younger speakers. That is not the case in Semerap, where language contact is minimal and people retain their linguistic identity.

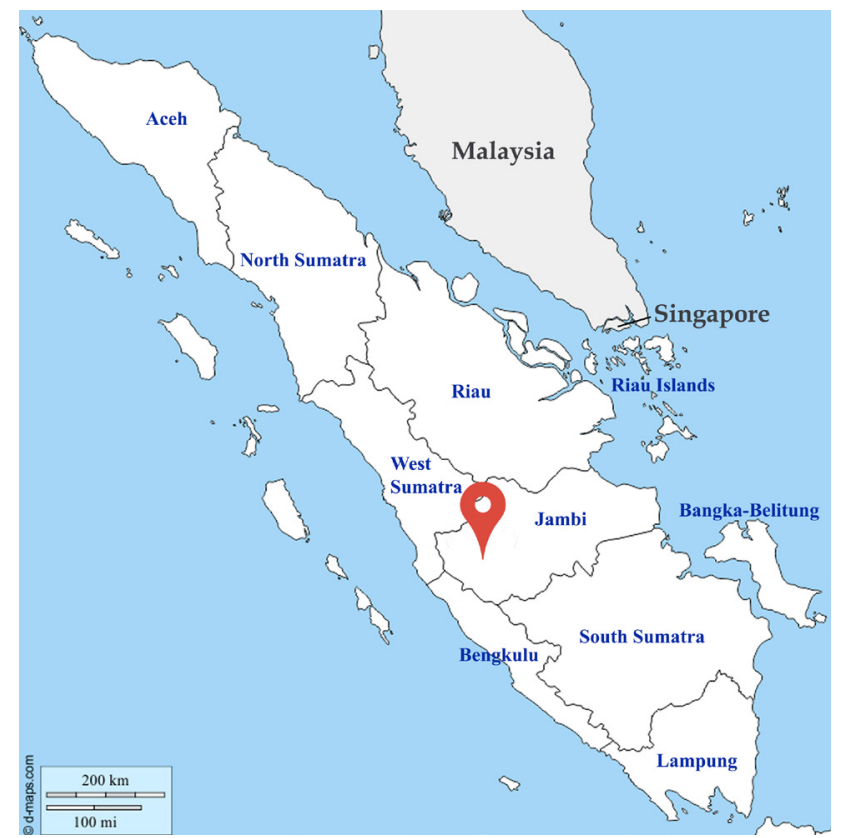

Figure 1. Map of Sumatra. (Source: https://d-maps.com/carte.php?num_ car=133864\&lang=en).

The goal of this article is to investigate the sound changes of an understudied Malayic variety, the Semerap dialect of Kerinci, from a comparative Malayic perspective. It provides a unique dataset and insights reinforced by broader historical linguistic implications. It also analyses some 
aspects of the morphophonology of the Semerap dialect, which are of historicophonological relevance. Section 2 outlines Semerap phonology, elaborating on its phonemes (consonants, sesqui-syllables, vowels, and diphthongs). Section 3 pays attention to phrasal alternation and its functions. As mentioned previously, this linguistic phenomenon makes Kerinci unique among other Malayic varieties. Section 4 focuses in detail on the historical sound changes underlying the Semerap dialect, comparing it with data from other Malay varieties. Section 5 reviews the impact of non-prenasalized voiced obstruent stops in Semerap, demonstrating how these phonemes affect the historical root-final ${ }^{*} \mathrm{~V}(\mathrm{C}) \#$ in word-final syllable rhymes.

The data of this study were collected by interviewing a number of Semerap native speakers. Besides elicitation, the informants also provided naturalistic data (daily conversations and story-telling). For the sake of completeness, a second fieldwork trip was conducted. During the data collection, I spoke Kerinci with the consultants to gain their trust quickly. For comparative purposes, I have also included data from other Malayic varieties, such as Minangkabau (MKB) in West Sumatra, Indragiri Hulu Riau (IHR) in Riau Mainland, and Sambas (SBS) in West Kalimantan. The Minangkabau data have been produced by myself, whereas the Indragiri Hulu Riau and the Sambas data were collected by interviewing native speakers of these languages. I have done so since no proto-Malayic reconstructions have been postulated for the majority of words discussed in this article. The point of such inter-dialectal comparisons, then, is to circumvent the caveat of treating contemporary Standard Malay as "the norm", if not the historical source from which other Malay varieties have sprung.

\section{Phonology}

Phonemes in SMR consist of consonants, vowels, and diphthongs, all of which will be discussed in this section.

\subsection{CONSONANTS}

There are twenty consonantal sounds in the Semerap dialect, as summarized in Table 2.

$\begin{array}{llllllll} & & \text { Labial } & \text { Dental } & \text { Alveolar } & \text { Palatal } & \text { Velar } & \text { Glottal } \\ \text { Stops } & \mathrm{Vl} & \mathrm{p} & \mathrm{t} & & \mathrm{c} & \mathrm{k} & \text { ? } \\ & \mathrm{V} & \mathrm{b} & & \mathrm{d} & \mathrm{J} & \mathrm{g} & \mathrm{h} \\ \text { Fricatives } & \mathrm{Vl} & & & \mathrm{s} & & \mathrm{x} & \\ & \mathrm{V} & & & & & \\ \text { Nasals } & & \mathrm{m} & \mathrm{n} & \mathrm{n} & \mathrm{n} & \\ \text { Laterals } & & & \mathrm{l} & & & \\ \text { Trills } & & \mathrm{r} & & & \\ \text { Glides } & \mathrm{w} & & & \mathrm{j} & \end{array}$

Table 2. Consonants in Semerap. 
Table 3 shows the distribution and realization of consonants in all positions; initial, medial, and final. In this regard, Semerap is slightly different from other dialects spoken in central Kerinci, such as Pondok Tinggi and Sungai Penuh. In Semerap, the velar voiceless stop occurs in the final position, and velar fricative in initial and medial positions. This has not been attested in other dialects spoken in central Kerinci.

\begin{tabular}{|c|c|c|c|}
\hline $\mathrm{C}$ & Word-initial (\#CV) & Word-medial (VCV) & Word-final (VC\#) \\
\hline$/ \mathrm{p} /$ & paygoay 'grilled.A' & lupeu 'to forget.O' & isoap 'to suck. $\mathrm{A}^{\prime}$ \\
\hline$/ \mathrm{b} /$ & buwia 'to bring. $A^{\prime}$ & cabek 'to withdraw.A' & - \\
\hline$/ \mathrm{t} /$ & taneuh 'soil.O' & matah 'raw. $\mathrm{A}^{\prime}$ & laloat 'fly.A' \\
\hline$/ \mathrm{d} /$ & daliam 'deep.A' & suduh 'finished.A' & - \\
\hline /c/ & cdi?'smart.A' & kacoay 'pulses.A' & - \\
\hline$/ \mathrm{d} /$ & yrnih 'clearA' & rajean 'diligent. $\mathrm{A}^{\prime}$ & - \\
\hline /k/ & kudua 'horse. $\mathrm{A}^{\prime}$ & pake 'to wear. $\mathrm{A}^{\prime}$ & ihak 'to inhale. $\mathrm{A}^{\prime}$ \\
\hline /g/ & gulia 'curry.A' & gigeat 'to bite. $\mathrm{A}^{\prime}$ & - \\
\hline$/ \mathrm{R} /$ & - & - & lape?'m \\
\hline$/ \mathrm{h} /$ & harto 'wealth.A' & bahea 'new.A' & abeah 'used up.A' \\
\hline /s/ & suaro 'voice. A' & bisia 'able. $\mathrm{A}^{\prime}$ & - \\
\hline$|x|$ & xoat 'slice. $\mathrm{A}^{\prime}$ & $p(\partial) x e u h$ 'to squeeze. $\mathrm{A}^{\prime}$ & - \\
\hline$/ \mathrm{m} /$ & mato 'eyes.A' & timay 'cucumber.A' & ajoam 'chicken.A' \\
\hline$/ \mathrm{n}$ & nasa 'cooked rice. $\mathrm{A}^{\prime}$ & manah 'sweet. A' & lilan 'candle.A' \\
\hline$/ \mathrm{n}$ & nan 'very' & bania?'ma & - \\
\hline$/ \mathrm{y} /$ & yo? 'breath' & tayaih 'c & ladiay 'dry field.A' \\
\hline$/ 1 /$ & luna?'soft. $\mathrm{A}^{\prime}$ & bliah 'to crack. A' & - \\
\hline$/ \mathrm{r} /$ & rame 'crowded.A' & suaro 'voice.A' & - \\
\hline$/ \mathrm{w} /$ & wakteu 'time.O' & siwan 'pants.O' & - \\
\hline$/ \mathrm{j} /$ & jaten 'orphan' & dakaja 'vegetables.A' & - \\
\hline
\end{tabular}

Table 3. Consonant distribution.

\subsection{SESQUI-SYLLABICITY}

The SMR phonology displays sesqui-syllabicity in words exhibiting initial consonant clusters (tpeu? 'to slap', lbiat 'dense'). In terms of length, the sesquisyllable can be defined as a syllable type between a monosyllable and a disyllable: a "syllable-and-a-half" (J. Matisoff 1990). A sesqui-syllable exhibits a word-final "major" syllable preceded by a "minor" syllable or pre-syllable (B.A. Butler 2014). According to A. Michaud (2012: 2), this minor syllable consists of "a simple consonant [...] plus an optional nucleus, V: either a vowel, or a sonorant (nasal or liquid) serving as nucleus. In the Austroasiatic domain, the most frequently encountered situation is one in which there can be no vowel contrast in the presyllable: the nucleus consists simply in a schwa, a noncontrastive, optional vowel". Butler (2014) identifies three properties of sesqui-syllabicity: prosodic prominence is word-final, minor syllables are phonologically reduced, and minor syllables are light.

For the SMR data, I propose two phonological hypotheses underlying the sesqui-syllabic data attested (Figure 2). First, there might be no intervening 
vowel between the initial consonant cluster (tpeu?, lbiat). The transition between the consonants is very quick, so that no vowel can be heard. Second, there might be an epenthetic schwa within the cluster (tºeu?, lobiat). In this case, there is a transition between the consonants with a schwa occurring in this transition $\left(\mathrm{C}^{\circ} \mathrm{C}\right)$. This insertion of a vowel nucleus prevents a violation of the sonority hierarchy (SSP: Sonority Sequencing Principle), see Figure 2. Whether this schwa is phonetic or underlying merits further research.

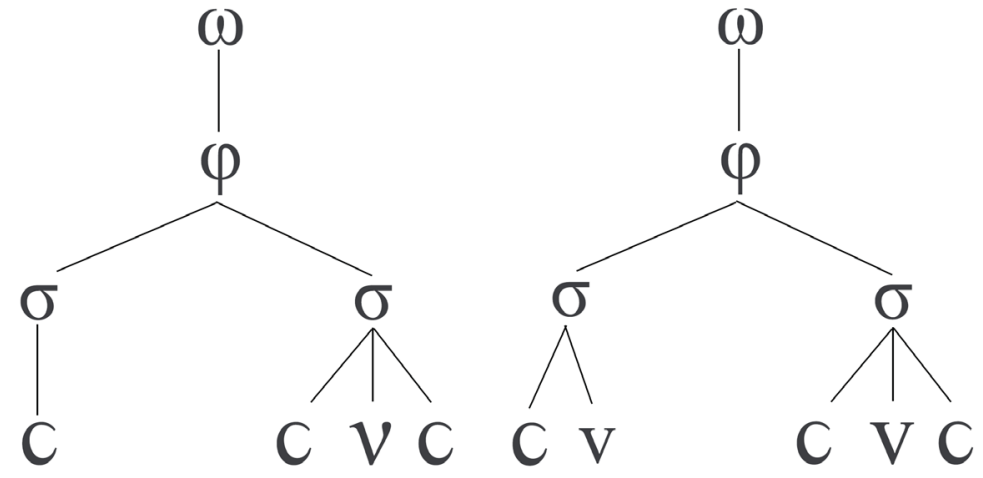

Figure 2. Sesqui-syllabicity.

\subsection{VOWELS}

Semerap exhibits eight vowels: three front vowels, two central vowels (of which the status of the schwa is uncertain), and three back vowels as can be seen in Table 4.

$\begin{array}{lccc}\text { Vowels } & \text { Front } & \text { Central } & \text { Back } \\ \text { Close (high) } & \mathrm{i} & & \mathrm{u} \\ \text { Close-mid } & \mathrm{e} & & \mathrm{o} \\ \text { Open-mid } & \varepsilon & (\partial) & \mathrm{o} \\ \text { Open (low) } & & \mathrm{a} & \end{array}$

Table 4. Vowels in Semerap.

The mid-front vowels and mid-back vowels do not appear in initial position. All vowels appear in medial positions except for a close-mid back vowel /o/, which only occurs word-finally and in diphthongs as in Table 5. The open mid-front vowel $/ \varepsilon /$ and open mid-back vowel $/ \mathrm{\rho}$ also do not occur in final position. The status of the schwa / $/$ / is not entirely clear. It is optional in initial and medial positions. However, it is difficult to ascertain whether it actually appears in those environments, because Semerap people speak relatively faster than other Kerinci people, such as those from Pondok Tinggi. 


\begin{tabular}{|c|c|c|c|}
\hline $\mathbf{V}$ & Word-initial (\#V(C)) & Word-medial (CVC) & Word-final (CV\#) \\
\hline /a/ & ajoam 'chicken. $\mathrm{A}^{\prime}$ & kaja 'wood.A' & nasa 'cooked rice. $\mathrm{A}^{\prime}$ \\
\hline $10 /$ & - & tpo? 'to slap.A' & - \\
\hline$/ \mathrm{e} /$ & - & saket 'ill.O' & lante 'floor. $\mathrm{A}^{\prime}$ \\
\hline$/ 2 /$ & (o)loay 'eagle. $\mathrm{A}^{\prime}$ & $p(\boldsymbol{\partial}) l o h$ 'sweat.A' & - \\
\hline$/ \varepsilon /$ & - & dapst 'get.O' & - \\
\hline /i/ & ima 'tiger. $\mathrm{A}^{\prime}$ & rajin 'diligent. $\mathrm{O}^{\prime}$ & gadi 'to pledge. $\mathrm{O}^{\prime}$ \\
\hline /o/ & - & - & namo 'name. $\mathrm{A}^{\prime}$ \\
\hline$/ \mathrm{u} /$ & uhoay 'people.A' & dahuh 'blood.O' & datu 'flat.O' \\
\hline
\end{tabular}

Table 5. Vowel distribution.

\subsection{DipHTONGS}

Semerap has four opening diphthongs and four closing diphthongs as shown in Table 6 . As we can observe, opening diphthongs are triggered by absolute forms and closing diphthongs by oblique forms (see Section 3).

\begin{tabular}{l|l} 
Opening diphthongs & \multicolumn{2}{c}{ Closing diphthongs } \\
\hline ua bawua 'to bring. $\mathrm{A}^{\prime}$ & eu lupeu 'to forget.O' \\
ea basea 'stale. $\mathrm{A}^{\prime}$ & ai nasai 'cooked rice.O' \\
ia gulia 'curry. $\mathrm{A}^{\prime}$ & oi kapoih 'cotton.O' \\
oa mahoan 'expensive. $\mathrm{A}^{\prime}$ & ui jahui 'finger.O'
\end{tabular}

Table 6. Diphthongs in Semerap.

\section{AbSOLUte AND Oblique ALternation}

Having previously given examples of Semerap words occurring in their A- and $\mathrm{O}$-forms, it is now time to address this alternation in more detail. A number of Kerinci dialects, such as Pondok Tinggi, Sungai Penuh, and Tanjung Pauh Mudik, exhibit the aforementioned phenomenon of "phrasal alternation", whereby almost all inherited words have at least two alternative forms with a distinct shape of their final syllable rhymes ${ }^{*} \mathrm{~V}(\mathrm{C}) \#$. The two alternating forms have been labelled absolute and oblique (Prentice and Usman 1978). ${ }^{2}$

(1)-(4) are instances of phrasal alternation in SMR. In (1), the semi-transitive verb masa? 'cook' occurs in the absolute form. In (2), the object gulia 'curry' triggers an oblique verb and makes the construction transitive, while the object itself appears in the absolute form. In (3), the addition of dagean 'meat'

1 Typologically, Semitic languages such as Arabic and Hebrew exhibit a related phenomenon of alternation called "construct state" (F. Abu Chacra 2018; G. Zuckermann 2006). However, in these languages, the alternation marks the possessee in a genitive construction.

2 Other researchers have named these two forms pausal and non-pausal form (E.O. van Reijn 1974), bentuk I and bentuk II (Usman 1988), and base form and secondary form (McKinnon et al. 2015). Following the most widespread convention and in line with my previous work, I stick with absolute and oblique in this article. 
modifying the head noun again triggers the oblique form, while the modifier itself remains absolute. In (4), the demonstrative ineh 'this' triggers the oblique form dagin 'meat'. As these examples demonstrate, the alternation between absolute and oblique forms is determined by their syntactic position in a phrase, whereby the absolute form occurs in phrase-final and the oblique form in phrase-medial position.

(1) ka masa?

1SG cook.A

'I cook.'

(2) ka masu? gulia

1SG cook.O curry.A

'I cook curry.'

(3) $k a$ masu? guli dagean

1SG cook.O curry.O meat.A

'I cook meat curry.'

(4) ka masu? guli dagin ineh

1SG cook.O curry.O meat.O DEM

'I cook this meat curry.'

The choice between absolute or oblique forms is not solely determined by syntactic position in a phrase. Contextual usage is another factor to be taken into account. When a noun phrase expresses a generic meaning, the absolute form is used. In (5), a cat kuce? is introduced for the first time, using the generic absolute form. In (6), it is modified by the third possessive pronoun $n o$. This makes the cat specific, triggering the oblique form kucoi?. In (7), the cat still occurs in the oblique form, even without a modifier. In this case, we must assume contextual familiarity between speech participants, as expressed by the oblique form.

(5) kuce?

cat.A

'a cat'

(6) kucoir no laha cat.O 3SG.POSS run.A

'His/her cat runs.'

(7) kucoir laha

cat.O run.A

'The cat runs.' 
On account of their semantic markedness, oblique forms typically occur phrase-medially. However, in some contexts, they can also appear phrasefinally. Below are some possible answers to the question "What is he doing?". In (8), the absolute verb is used to indicate the activity of climbing in general, leaving unspecified what is being climbed. When it precedes an object ("a tree"), the verb occurs in the oblique form, as in (9). When it appears on its own in the oblique form, as in (10), the verb 'to climb' indicates that what is being climbed is known from the context, although it is syntactically covert.

(8) manjoat

ACT.climb.A

'climbing'

(9) manjat umpey kaja

ACT.climb.O clump.O wood.A

'climbing a tree'

(10) manjat

ACT.climb.O

'climbing it'

Besides signalling syntactic differences and indicating specificity, phrasal alternation also has some lexical characteristics. In (11), the adjective kunan 'yellow' which appears in the absolute form in the noun phrase bajiu kunan has two meanings: 'a yellow shirt' and, by association, 'a policeman' (compare (12)). Only the absolute form "can" produce compound meanings of the latter type. This is also attested in the Pondok Tinggi dialect of Kerinci (Ernanda 2017: 126) and possibly Kerinci-wide, although more research is needed to determine it.
(11) bajiu kunan
shirt.O yellow.A
'a yellow shirt'
'a policeman'
(12) bajiu kunen
shirt.O yellow.O
'the yellow shirt'
*'the policeman'

\section{SOUND CHANGES}

This section examines the diachronic changes of Semerap phonemes. For comparative purposes, I shall provide not only the Semerap data, but also equivalents in Standard Malay (SM), Minangkabau (MKB), the Malay of Inderagiri Hulu Riau (IHR), and that of Sambas (SBS). The reconstructed sounds of proto-Malayic are based on the work of K.A. Adelaar (1992). 


\subsection{VOWELS}

In non-final syllables, the phoneme / $i$ / in SMR (proto-Malayic *i) has occasionally undergone lowering to /e/ in SM, MKB, and IHR. However, these varieties are not consistent in this regard and alternate between / $\mathrm{i} /$ and /e/. Along the same lines, the phoneme / $u$ / in SMR corresponds to / $u$ / in MKB (proto-Malayic *u), whereas SM and IHR display this vowel alternatingly with a lowered /o/. Even in the loanword for 'coffee', SMR regularly exhibits /u/. See Table 7 .

\begin{tabular}{|c|c|c|c|c|}
\hline SMR & SM & MKB & IHR & GLOSS \\
\hline ils?/ileu? & elo? & elo? & (mole?) & 'lovely' \\
\hline mizia/mizu & тела & тела & теда & 'table' \\
\hline cipa?/cipeu? & sepa? & sipa? & sepa? & 'to kick' \\
\hline cubua & coba & cubo & cubo & 'to try' \\
\hline uhoay/uhay & oray & uray & oyaך & 'people' \\
\hline kupai & kopi & kopi & kopi & 'coffee' \\
\hline
\end{tabular}

Table 7. Vowel sounds.

In Table 8, the SMR phoneme / a/ in the first syllable corresponds to / $/$ / in SM, /o/ in IHR, and /a/ in MKB and SBS (proto-Malayic *a).

$\begin{array}{llllll}\text { SMR } & \text { SM } & \text { MKB } & \text { IHR } & \text { SBS } & \text { GLOSS } \\ \text { barsih/barsuih } & \text { barsih } & \text { barasiah } & \text { boseh } & \text { barseh } & \text { 'clean' } \\ \text { karteh/kartoih } & \text { kartas } & \text { karateh } & \text { kotas } & \text { karatas } & \text { 'paper' } \\ \text { matah/mateuh } & \text { montah } & \text { matah } & \text { montah } & \text { manta? } & \text { 'raw' }\end{array}$

Table 8. Phoneme /a/.

\subsection{CONSONANTS}

Based on my observations on the Semerap dialect, a number of consonantal phenomena will be discussed next.

\subsubsection{Word-final ${ }^{*} p \#$ and ${ }^{*} t \#$}

The velar stop / k/ in word-final position is not attested in other Kerinci dialects, such as Sungai Penuh, Pondok Tinggi, and Tanjung Pauh Mudik, nor in most Malay dialects, in which a word-final $/ \mathrm{k} /$ is pronounced as a glottal stop / $\mathrm{l} /$. It corresponds to either /p/ or / t/ in SM, IHR, and SBS (proto-Malayic * $\mathrm{p} \#$ and *t\#) and to a glottal stop in Minangkabau. See Table 9. 


$\begin{array}{llllll}\text { SMR } & \text { SM } & \text { MKB } & \text { IHR } & \text { SBS } & \text { GLOSS } \\ \text { ideak/idik } & \text { hidup } & \text { idui? } & \text { idop } & \text { idup } & \text { 'to live' } \\ \text { cukak/cukek } & \text { cukup } & \text { cukui? } & \text { cukop } & \text { cukup } & \text { 'enough' } \\ \text { ihak/ihek } & \text { hirup } & \text { irui? } & \text { ifop } & \text { irup } & \text { 'to sniff' } \\ \text { tutak/tutek } & \text { tutup } & \text { tutui? } & \text { tutop } & \text { tutup } & \text { 'to close' } \\ \text { cabek/cabik } & \text { cabut } & \text { cabui? } & \text { cabot } & \text { cabut } & \text { 'to withdraw' } \\ \text { kabek/kabik } & \text { kabut } & \text { kabui? } & \text { kabot } & \text { kabut } & \text { 'fog' } \\ \text { lutak/lutek } & \text { lutut } & \text { lutui? } & \text { lutot } & \text { lutut } & \text { 'knee' } \\ \text { takak/takek } & \text { takut } & \text { takui? } & \text { takot } & \text { takut } & \text { 'afraid' }\end{array}$

Table 9. Word-final * $\mathrm{p} \#$ and *t\#.

\subsection{2/ $/ 2$}

For the words 'to take' and 'small', a glottal stop occurs in final position in all varieties except in SM, which shows the phoneme /1/ in this position (see Table 10). This discrepancy has already been noted by Adelaar (1992: 90), who reconstructs both *kacil $\sim k a c i$ ? and *ambil *ambi?. The realization of the word 'to dig out' varies across varieties.

$\begin{array}{llllll}\text { SMR } & \text { SM } & \text { MKB } & \text { IHR } & \text { SBS } & \text { GLOSS } \\ \text { amber/ambai? } & \text { ambil } & \text { ambia? } & \text { ambe? } & \text { ambe? } & \text { 'to take' } \\ \text { cukai? } & \text { cuykil } & \text { cukia } & \text { cuket } & \text { cuykel } & \text { 'to dig out' } \\ \text { kcai? } & \text { kacil } & \text { kete? } & \text { koci? } & \text { kaci? } & \text { 'small' }\end{array}$

Table 10. The glottal stop / ?/.

\subsubsection{Word-final nasals}

In Table 11, the alveolar nasal in SMR corresponds to a velar nasal in Malayic varieties (proto-Malayic * $¥ \#$ ) when preceded by /i/, while the velar nasal corresponds to an alveolar nasal (proto-Malayic *n\#) when preceded by $/ \mathrm{u} /$. Other Kerinci varieties do not show the particular realization, in which /i/ apparently triggers alveolarity and / $\mathrm{u} /$ velarity. ${ }^{3}$

\begin{tabular}{|c|c|c|c|c|c|}
\hline SMR & SM & MKB & IHR & SBS & GLOSS \\
\hline guntean/guntin & guntin & guntiay & gunter & guntin & 'scissors' \\
\hline malan/malen & maliy & maliay & maley & malin & 'thief' \\
\hline kunan/kunen & kunin & kuniay & kuney & kunin & 'yellow' \\
\hline kbeay/kbin & kabun & kabun & kobon & kabon & 'garden' \\
\hline daeay/dain & daun & daun & daon & daun & 'leaf' \\
\hline timay/timey & timun & timun & timon & timun & 'cucumber' \\
\hline tuhay/tuhey & turun & turun & tuyon & turun & 'to go down' \\
\hline
\end{tabular}

Table 11. Word-final nasals.

\footnotetext{
${ }^{3}$ In the Pondok Tinggi dialect (PT), all historical nasals have become alveolar (gunton, malan, kunan, kaben, daen, timan, tuhan), whereas in the Koto Keras dialect (KK) they became velar

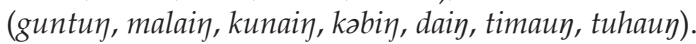


In SMR, an alveolar nasal / $\mathrm{n} /$ in word-final position corresponds to an alveolar lateral /1/ in SM, IHR, and SBS (proto-Malayic *1\#). MKB loses this consonant in final position. See Table 12.

\begin{tabular}{|c|c|c|c|c|c|}
\hline SMR & SM & MKB & IHR & SBS & GLOSS \\
\hline bantian/banten & bantal & banta & bantal & bantal & 'pillow' \\
\hline gatian/gaten & gatal & gata & gatal & gatal & 'itchy' \\
\hline juwian/Juwen & jual & juwa & jual & fual & 'to sell' \\
\hline samboan/samban & sambal & samba & sambal & sambal & 'chili sauce' \\
\hline mahoan/mahan & mahal & maha & mahal & mahal & 'expensive' \\
\hline tingoan/tingan & tingal & tinga & tingal & tingal & 'remain' \\
\hline kancen/kancean & kancil & kancia & kancel & kancil & 'mouse deer' \\
\hline btun & botul & batua & botol & batol & 'true' \\
\hline kumpsn & kumpul & kитриа & kumpol & kumpol & 'to gather' \\
\hline
\end{tabular}

Table 12. The alveolar nasal /n/.

\section{$4.2 .4 / x /$}

In Table 13, the SMR segment / $\mathrm{x}$ / corresponds to / or / in SM, / ar/ in MKB and SBS, and /oy/ in IHR (proto-Malayic ${ }^{*}$ CorV). The phoneme / x/ is not attested in other Kerinci dialects and it is relatively uncommon in Malayic and Austronesian languages in general, especially as a phoneme not introduced by language contact. Words which exhibit this phoneme tend to be disyllabic and feature the segment in the first syllable. When $/ x /$ is preceded by a historical word-initial ${ }^{*} \mathrm{k}$, the latter phoneme is elided.

\begin{tabular}{|c|c|c|c|c|c|}
\hline SMR & SM & МКВ & IHR & SBS & GLOSS \\
\hline pxeuh/pxoh & paras & parah & poyah & paras & 'to press' \\
\hline bxiat/bxet & borat & bare? & boyat & barat & 'heavy' \\
\hline xoat/xat & karat & kare? & kojat & karat & 'to cut' \\
\hline xan/xen & kariq & kariay & koyey & kariy & 'dry' \\
\hline xah/xaih & karis & karih & koyes & karis & 'kris' \\
\hline bxu?/bxiu? & baru? & barua? & bоуи? & baro? & 'short-tailed macaque' \\
\hline$t x \supset y / t x \varepsilon y$ & taruy & taruay & toyoy & taroy & 'eggplant' \\
\hline pxak/pxek & parut & parui? & poyot & parut & 'stomach' \\
\hline bxiah/bxih & baras & bareh & boyas & baras & 'uncooked rice' \\
\hline
\end{tabular}

Table 13. The voiceless velar fricative $/ x /$.

\section{$4.2 .5 / h /$}

The word-initial voiceless glottal fricative / $\mathrm{h} /$ is only attested in SM. All other Malay varieties lack the phoneme in this position. See Table 14. 


\begin{tabular}{|c|c|c|c|c|c|}
\hline SMR & SM & MKB & IHR & SBS & GLOSS \\
\hline itoam/itam & hitam & itam & itam & itam & 'black' \\
\hline antoam/antam & hantam & antam & ontam & antam & 'to fight' \\
\hline ujian/ujen & hufan & ufan & ufan & ufan & 'rain' \\
\hline iloay/ilay & hilay & ilay & ilay & ilay & 'be lost' \\
\hline utoay/utay & hutay & utai & utay & utay & 'debt' \\
\hline adiap/adep & hadap & ado? & adap & adap & 'to face' \\
\hline ayoat/ayat & hayat & aye? & ayat & ayat & 'warm' \\
\hline izia/izu & hizau & izau & iyau & iyau & 'green' \\
\hline aha/ahai & hari & ari & $a_{y i}$ & ari & 'day' \\
\hline impat/impet & himpit & impi? & impet & rimpi? & 'to coincide' \\
\hline iduy/idin & hiduy & iduay & idoy & idoy & 'nose' \\
\hline 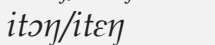 & hituy & ituay & iton & itoy & 'to count' \\
\hline ideak/idik & hidup & idui? & idop & idup & 'to live' \\
\hline ihak/ihek & hirup & irui? & іуор & irup & 'to sniff' \\
\hline ayah/ayaih & hayus & ayuih & ayos & ayus & 'burnt' \\
\hline alah/alaih & halus & aluih & alos & alus & 'soft' \\
\hline apah/apuh & hapus & apuih & apos & apus & 'to erase' \\
\hline anak/anek & hanut & anui? & anot & anut & 'washed away' \\
\hline
\end{tabular}

Table 14. The voiceless glottal fricative /h/.

However, in some Sanskrit loanwords as given in Table 15, the / $\mathrm{h} /$ is retained word-initially except in IRH, where we can see a process of metathesis.

$\begin{array}{llllll}\text { SMR } & \text { SM } & \text { MKB } & \text { IHR } & \text { SBS } & \text { GLOSS } \\ \text { harto/harteu } & \text { harta } & \text { harato } & \text { gotə } & \text { hartə } & \text { 'wealth' } \\ \text { hargu } & \text { harga } & \text { harago } & \text { gogə } & \text { harga } & \text { 'price' }\end{array}$

Table 15. The voiceless glottal fricative / $\mathrm{h} /$ in Sanskrit loanwords.

Word-medially, the phoneme / $\mathrm{h} /$ is unattested in SMR and most other Malayic varieties, again with the exception of SM. See Table 16.

$\begin{array}{llllll}\text { SMR } & \text { SM } & \text { MKB } & \text { IHR } & \text { SBS } & \text { GLOSS } \\ \text { paat/paet } & \text { pahit } & \text { pai? } & \text { paet } & \text { pai? } & \text { 'bitter' } \\ \text { taan } & \text { tahun } & \text { taun } & \text { taon } & \text { taun } & \text { 'year' } \\ \text { naat } & \text { fahit } & \text { fai? } & \text { faet } & \text { fai? } & \text { 'to sew' }\end{array}$

Table 16. The unattested voiceless glottal fricative / $\mathrm{h} /$ in word-medial position.

However, as depicted in Table 17, it is retained in all varieties in loanwords and between (historically) identical vowels. 


$\begin{array}{llllll}\text { SMR } & \text { SM } & \text { MKB } & \text { IHR } & \text { SBS } & \text { GLOSS } \\ \text { mahoan/mahan } & \text { mahal } & \text { maha } & \text { mahal } & \text { mahal } & \text { 'expensive' } \\ \text { sihoat/sihat } & \text { sehat } & \text { sehat } & \text { sehat } & \text { sehat } & \text { 'healthy' } \\ \text { dahian/dahen } & \text { dahan } & \text { dahan } & \text { dahan } & \text { dahan } & \text { 'branch' } \\ \text { tahoan/tahan } & \text { tahan } & \text { tahan } & \text { tahan } & \text { tahan } & \text { 'invulnerable' } \\ \text { khaj }^{4} & \text { garaham } & \text { garaham } & \text { gryaham } & \text { garahay } & \text { 'molar' }\end{array}$

Table 17. The voiceless glottal fricative / h/ in loanwords.

In word-medial position, /h/ in SMR corresponds to / $\mathrm{r} /$ in SM, MKB, and SBS and / $\mathrm{y} /$ in IHR (proto-Malayic ${ }^{*} \mathrm{VrV}$ ) as given in Table 18.

\begin{tabular}{|c|c|c|c|c|c|}
\hline SMR & SM & MKB & IHR & SBS & GLOSS \\
\hline dahiah/dahuh & darah & darah & daya & darah & 'blood' \\
\hline uhoay/uhay & oray & uray & oyay & uray & 'people' \\
\hline ahoay/ahay & aray & aray & ayay & aray & 'charcoal' \\
\hline siheh/sihaih & sirih & siriah & sife & sireh & 'betel quid' \\
\hline buhu?/buhiu? & buru? & burua? & вияо? & buro? & 'ugly' \\
\hline suhoat/suhat & surat & sure? & suyat & surat & 'letter' \\
\hline ihah/ihuih & iris & irih & ijes & iris & 'to slice' \\
\hline laha/lahai & lari & lari & layi & lari & 'to run' \\
\hline kihay & kirim & kirim & kijem & kirim & 'to send' \\
\hline suhoh/suheuh & suruh & suruah & suуo & suroh & 'to order' \\
\hline buhuy & buruy & buruay & buуoy & buroy & 'bird' \\
\hline tuhan & turun & turun & tuyon & turun & 'to go down' \\
\hline
\end{tabular}

Table 18. The attested voiceless glottal fricative / h/in word-medial position.

In the SMR word kheh kreh 'hard' (SM kras, MKB kareh, IHR koyas, SBS karas), both $/ \mathrm{h} /$ and $/ \mathrm{r} /$ can be used interchangeably without changing the meaning. Phonologically, kheh is sesqui-syllabic / $k$.heh/ rather than aspirated / $k^{h} e h /$.

In world-final position, however, /h/ in SMR corresponds to / s/ in SM,

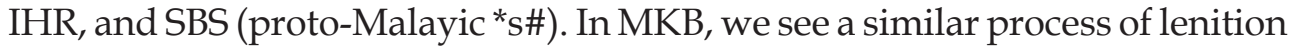
to $/ \mathrm{h} /$. See Table 19.

${ }^{4}$ SMR exhibits a shortened form. 


$\begin{array}{llllll}\text { SMR } & \text { SM } & \text { MKB } & \text { IHR } & \text { SBS } & \text { GLOSS } \\ \text { gliah/glih } & \text { galas } & \text { galeh } & \text { golas } & \text { galas } & \text { 'glass' } \\ \text { pdiah/pdih } & \text { padas } & \text { padeh } & \text { podas } & \text { padas } & \text { 'spicy' } \\ \text { baliah/balih } & \text { balas } & \text { baleh } & \text { balas } & \text { balas } & \text { 'to reply' } \\ \text { kapeh/kapoih } & \text { kapas } & \text { kapeh } & \text { kapas } & \text { kapas } & \text { 'cotton' } \\ \text { bareah/baruih } & \text { baris } & \text { barih } & \text { bayes } & \text { baris } & \text { 'line' } \\ \text { manah/manaih } & \text { manis } & \text { manih } & \text { manes } & \text { manis } & \text { 'sweet' } \\ \text { tipah/tipaih } & \text { tipis } & \text { tipih } & \text { tipes } & \text { tipis } & \text { 'thin' } \\ \text { putah/putaih } & \text { putus } & \text { putuih } & \text { putos } & \text { putus } & \text { 'broken off' } \\ \text { alah/alaih } & \text { halus } & \text { aluih } & \text { alos } & \text { alus } & \text { 'soft' }\end{array}$

Table 19. The voiceless glottal fricative / $\mathrm{h} /$ in word-final position.

\subsubsection{Alveolar trills}

Except for loanwords, in Table 20, the alveolar trill / $\mathrm{r} /$ in SMR is only retained word-initially, corresponding to / $\mathrm{r} /$ in the other Malayic varieties and / $\mathrm{y} /$ in IHR (proto-Malayic *\#r).

\begin{tabular}{|c|c|c|c|c|c|}
\hline SMR & SM & MKB & IHR & SBS & GLOSS \\
\hline rabeay/rabin & rabun & rabun & yabon & rabun & 'near sighted' \\
\hline rdea? & radup & - & godop & radup & 'dull' \\
\hline rbek/rbik & rabut & rabui? & jobot & rabut & 'to snatch away' \\
\hline rataih & ratus & ratuih & yatos & ratus & 'hundred' \\
\hline ribea & ribu & ribu & jibu & ribu & 'thousand' \\
\hline rajean/rajin & rajin & rajin & rajen & rajin & 'diligent' \\
\hline rame/ramoi & ramai & ramai & jamai & ramai & 'crowded' \\
\hline rapsh/rapeuh & rapuh & rapuah & yopas & rapuh & 'brittle' \\
\hline carito/cariteu & carita & carito & cita & carita & 'story' \\
\hline driah/drih & daras & dareh & doyas & daras & 'swift' \\
\hline jarawiat/_arawet & forawat & jarawe? & foyawat & forawat & 'pimple, acne' \\
\hline frnih/srnuih & farnih & janiah & joneh & yarneh & 'clear' \\
\hline bareah/baruih & baris & barih & bayes & baris & 'line' \\
\hline fareay/zarin & farum & farum & fayom & jarum & 'needle' \\
\hline
\end{tabular}

Table 20. The alveolar trill /r/.

\subsection{HistORICAL INFIXES}

Historical infixes are somewhat understudied in comparative Malay linguistics. In certain cases, SMR shows different reflexes from other Malayic varieties for words with the historical infixes (or infix-resembling syllables) ${ }^{*}$ CorV or *ColV (see Table 21). These segments are absent in the words kbia/ kbu 'buffalo', khay 'molar', kinca/kincai 'Kerinci', pijo?/pijeu? 'cooking pot', and simak/simek'blanket'. In the word karpak/karpeuk' wing', conversely, SMR display an infix, whereas other Malayic attestations lack one. For baruwiay/

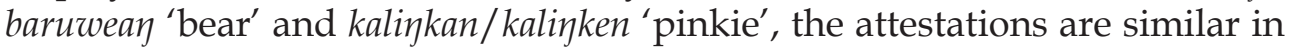
all varieties, whereas for karawa/karaweu 'bat', SMR displays an *CorV infix 
whereas all other varieties display an ${ }^{*} \mathrm{ColV}$ infix. In general, the data shows a preference in SMR for shorter segments.

\begin{tabular}{|c|c|c|c|c|c|}
\hline SMR & SM & MKB & IHR & SBS & GLOSS \\
\hline 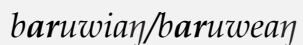 & boruay & baruway & bоуиап & boruay & 'bear' \\
\hline ija?/kijeu? & katiya? & katiya? & katiya? & kalintija? & 'armpit' \\
\hline 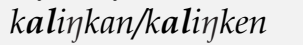 & 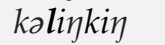 & kalijkiay & kalinkin & kalinkin & 'pinkie' \\
\hline karawa/karaweu & kalolawar & kalaluway & kololawa & kolawar & 'bat' \\
\hline karpak/karpeuk & kәра? & kapa? & kopa? & kapa? & 'wing' \\
\hline kbia/kbu & karbau & kabau & kobau & karabau & 'buffalo' \\
\hline khay & goraham & garaham & gəyaham & gorahay & 'molar' \\
\hline nca/kincai & karinci & karinci & karinci & karinci & 'Kerinci' \\
\hline jo?/pijeu? & pariju? & parijua? & pijo? & - & 'cooking pot' \\
\hline simak/simek & solimut & salimui? & salimot & - & 'blanket' \\
\hline
\end{tabular}

Table 21. The historical infixes *CərV or *CəlV.

\subsection{ISOLATED INNOVATIONS}

Other minor changes have been observed in consonants. The word-initial palatal voiceless stop corresponds /c/ to an alveolar fricative /s/ in the word cipa?/cipeu? ‘to kick' (SM: sepa?, MKB: sipa?, IHR: sepa?). In one isolated example, the labial voiced stop / b/ alternating with a labial voiceless stop / $\mathrm{p} /$ without any change in meaning: bdia?/bdu? vs. pdia?/pdu? 'talcum powder'.

\section{K-WORDS AND G-WORDS}

As mentioned previously, the phonological alternations in Semerap are realized through a four-way split. Two factors, absolute versus oblique, have been addressed in Section 3. This section discusses the remaining two, K-words and G-words. Prentice and Usman (1978) have coined these terms, which have since been adopted by other scholars of Kerinci. This four-way split in the reflection of word-final syllable rhymes $\left({ }^{*} \mathrm{~V}(\mathrm{C}) \#\right)$ is conditioned by the presence of a non-prenasalized voiced obstruent stop (/b/, /d/, /g/, and $/ J /$ ) in the root. Words which contain such a non-prenasalized voiced stop are conventionally called G-words, whereas words that lack them are called K-words. Table 22 compares the reflections of *ak\# for absolute and oblique forms.

\begin{tabular}{|l|l|l|l|l|l|l|}
\hline Earlier form & jina? & bana? & ana? & sepa? & omba? & bər-ana? \\
\hline SMR.A & jinia? & bania? & ana? & cipa? & umba? & bania? \\
\hline SMR.O & дinu? & banu? & aneu? & cipeu? & umbeu? & banu? \\
\hline Gloss & 'tame' & 'many' & 'child' & 'to kick' & 'wave' & 'to have a child' \\
\hline
\end{tabular}

Table 22. The reflections of root-final *ak\# in G- and K-words.

As Table 23 shows, the historical word-final * $i \#$ and * $u \#$ correspond to SMR ea\# in G-words and $a \#$ in K-words in the absolute form. This shows that 
G-words in word-final position are realized in a higher position than K-words. G-phonemes also trigger vowel raising in other Kerinci dialects (Ernanda 2017; Steinhauer 1978, 2002, 2018; McKinnon 2011).

\begin{tabular}{|l|l|l|}
\hline${ }^{*} \mathbf{i} \#$ & G-words & K-words \\
\hline Earlier form & basi & nasi \\
\hline SMR.A & basea & nasa \\
\hline SMR.O & basui & nasai \\
\hline Gloss & 'stale' & 'cooked rice' \\
\hline${ }^{*}$ u\# & G-words & K-words \\
\hline Earlier form & bulu & malu \\
\hline SMR.A & bulea & mala \\
\hline SMR.O & buliu & maleu \\
\hline Gloss & 'hair' & 'ashamed' \\
\hline
\end{tabular}

Table 23. The realization of word-final ${ }^{*} \mathrm{i} \#$ and ${ }^{*} \mathrm{u} \#$.

The occurrence of a homorganic nasal preceding the voiced stop does not affect the shape of the word-final syllable (Table 24). These words behave like $\mathrm{K}$-words, as is also the case in other Kerinci dialects.

\begin{tabular}{|l|l|l|}
\hline *at\# & K-words & G-words \\
\hline Earlier form & lambat & labat \\
\hline ABS & lamboat & lbiat \\
\hline OBL & lambat & lbct \\
\hline Gloss & 'slow' & 'dense' \\
\hline
\end{tabular}

Table 24. The occurrence of a homorganic nasal.

Table 25 presents the SMR reflections of all inherited root final ${ }^{*} \mathrm{~V}(\mathrm{C}) \#$ in this four-way split. The first column represents the codas of the root-final syllables and the top row all possible root nuclei. These are divided between G-words and K-words respectively. Each box contains the reflection of the given ${ }^{*} \mathrm{~V}(\mathrm{C}) \#$ in the absolute form and the oblique form. The status of some patterns $\left({ }^{*} \mathrm{~m} \#,{ }^{*} \mathrm{l} \#\right)$ is somewhat uncertain, as they display very few inherited words in SMR and in Malayic varieties in general (see Adelaar 1992). 


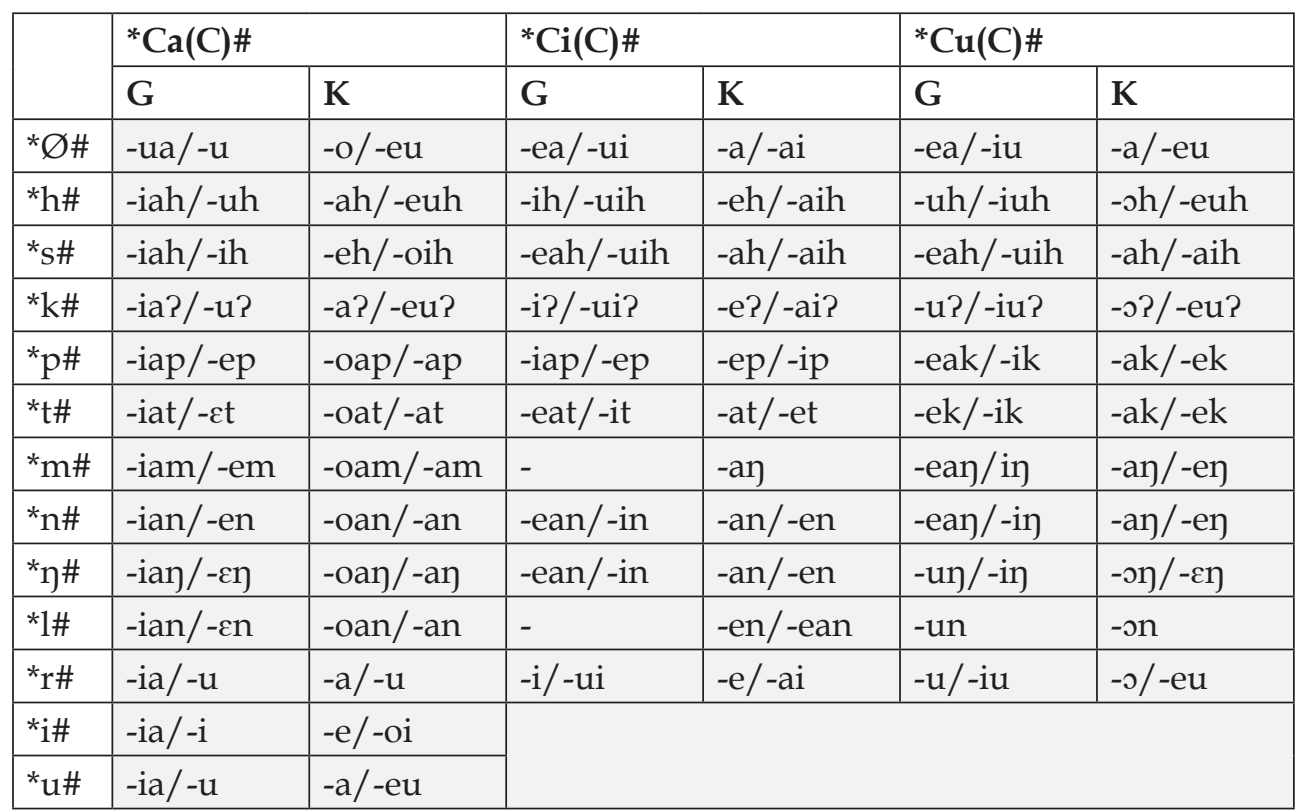

Table 25. Reflections of inherited root final *V(C)\#.

In Tables 26-28, I will provide examples of each inherited root final. The syllable rhyme ${ }^{*} \mathrm{Ca}(\mathrm{C}) \#$ is covered in Table $26,{ }^{*} \mathrm{Ci}(\mathrm{C}) \#$ in Table 27 , and ${ }^{*} \mathrm{Cu}(\mathrm{C}) \#$ in Table 28.

\begin{tabular}{|c|c|c|c|c|}
\hline & Earlier form & G-words & Earlier form & K-words \\
\hline *Ø\# & *kuda 'horse' & kudua/kudu & *mata 'eyes' & mato/mateu \\
\hline *h\# & *mudah 'easy' & mudiah/muduh & *kunah 'to chew' & kunah/kuneuh \\
\hline${ }^{*} \mathrm{~s} \#$ & *galas 'glass' & gliah/glih & *kapas 'cotton' & kapeh/kapoih \\
\hline *k\# & *yina?'tame' & діnia?/yinu? & *luna?'soft' & luna?/luneu? \\
\hline *p\# & *hadap 'facing' & adiap/adep & *asap 'smoke' & asoap/asap \\
\hline *t\# & ${ }^{*}$ dapat 'to get' & dapiat/dapet & *surat 'letter' & suhoat/suhat \\
\hline${ }^{*} \mathrm{~m} \#$ & *tajam 'sharp' & tajiam/tajem & *ajam 'chicken' & ajoam/ajam \\
\hline *n\# & *badan 'body' & badian/baden & *makan 'to eat' & makoan/makan \\
\hline *ฤ\# & *bonay 'thread' & bniay/bncy & *hutay 'debt' & utoay/utay \\
\hline *1\# & *bantal 'pillow' & bantian/banten & *kapal 'ship' & kpoan/kpan \\
\hline${ }^{*} \mathrm{r} \#$ & *datar 'flat' & datia/datu & *akar 'root' & aka/akeu \\
\hline *i\# & *gulai 'curry' & gulia/guli & *suyai 'river' & suye/sujoi \\
\hline${ }^{*} \mathrm{u} \#$ & *karbau 'buffalo' & kbia/kbu & *pisau 'knife' & pisa/piseu \\
\hline
\end{tabular}

Table 26. Semerap reflections of inherited root-final * $\mathrm{Ca}(\mathrm{C}) \#$. 


\begin{tabular}{|c|c|c|c|c|}
\hline & Earlier form & G-words & Earlier form & K-words \\
\hline${ }^{*} \varnothing \#$ & *basi 'stale' & basea/basui & *tali 'rope' & tala/talai \\
\hline *h\# & "sadih 'sad' & sdih/sduih & *pilih 'to choose' & pileh/pilaih \\
\hline${ }^{*} \mathrm{~s} \#$ & ${ }^{*}$ gadis 'girl' & gadeah/gaduih & *tipis 'thin' & tipah/tipaih \\
\hline${ }^{*} \mathrm{k} \#$ & *cordi? 'smart' & cdir/cdui? & *tarik' to pull' & tahe?/tahai? \\
\hline${ }^{*} \mathrm{p} \#$ & ${ }^{*} k a d i p^{5}$ 'to blink' & $k$ diap/kdep & ${ }^{*}$ sirip 'fin' & sirep/sirip \\
\hline${ }^{*} \mathrm{t} \#$ & ${ }^{*}$ cubit 'to pinch' & cibeat/cibit & *sakit 'sick' & sakat/saket \\
\hline${ }^{*} \mathrm{~m} \#$ & - & - & *kirim 'to send' ${ }^{6}$ & kihay \\
\hline *n\# & *dinin 'cold' & dinean/dinin & *cincin 'ring' & cincan/cincen \\
\hline *n\# & "guntip 'scissor' & guntean/guntin & ${ }^{*}$ mali ' 'thief' & malan/malen \\
\hline *l\# & & & *kancil 'mousedeer' & kancen/kancean \\
\hline${ }^{*} r \#$ & *gilir 'turn' & gili/gilui & * pikir 'to think' & pike/pikai \\
\hline
\end{tabular}

Table 27. Semerap reflections of inherited root-final * $\mathrm{Ci}(\mathrm{C}) \#$.

\begin{tabular}{|c|c|c|c|c|}
\hline & Earlier form & G-words & Earlier form & K-words \\
\hline *Ø\# & *batu 'stone' & batea/batiu & *kaju 'wood' & kaja/kajeu \\
\hline *h\# & *bunuh 'to kill' & bunuh/buniuh & *musuh'enemy' & musoh/museuh \\
\hline *s\# & *rabus 'to cook' & beah/buih & *hayus 'burnt' & ayah/ayaih \\
\hline *k\# & *dudu? 'to sit' & dudu?/dudiu? & *topuk 'to slap' & tpo?/tpeu? \\
\hline *p\# & *hidup 'to live' & idear/idi? & *hirup 'to inhale' & ihak/ihek \\
\hline *t\# & *kabut 'mist' & kabe?/kabi? & *lutut 'knee' & lutak/lutek \\
\hline *m\# & *farum 'needle' & jarean/farin & *minum 'to drink' & minay/miney \\
\hline *n\# & *sabun 'soap' & sabeay/sabin & *racun 'poison' & acay/acey \\
\hline *り\# & *gunuך 'mountain' & gunuү/gunin & *kaluy 'necklace' & 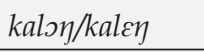 \\
\hline *1\# & *batul 'correct' & btun & *kumpul 'to get together' & kumpon \\
\hline *r\# & *dapur 'kitchen' & dapu/dapiu & *kasur 'mattress' & kaso/kaseu \\
\hline
\end{tabular}

Table 28. Semerap reflections of inherited root-final ${ }^{*} \mathrm{Cu}(\mathrm{C}) \#$.

Table 29, conversely, lists all SMR vowels attested in word-final syllables, followed by all possible historical conditions which could have triggered them. This will help future scholars to situate lexical data from SMR in relation to other Malayic varieties. In addition, it illustrates the complexity of historical sound changes in SMR and other varieties of Kerinci.

5 This is the only example of a G-word ending in *ip\#.

6 This is the only example of an inherited K-word ending in *im\#. Also consider the Arabic loanword musen 'season' (< musim). Both forms lack phrasal alternation.

7 This is the only example of a K-word ending in *il\#. 


\begin{tabular}{|c|c|c|}
\hline $\begin{array}{l}\text { Attested } \\
\text { vowel }\end{array}$ & Historical conditions & Example \\
\hline$-\mathrm{Ca}(\mathrm{C})$ & $\begin{array}{l}<* \mathrm{a} /[\mathrm{r}, \mathrm{u}, \mathrm{h}, \mathrm{k \#}]_{[+\mathrm{ABS}+\mathrm{K}]}[\mathrm{p}, \mathrm{t}, \mathrm{l}, \mathrm{N \#}]_{[+\mathrm{OBL}+\mathrm{K}]} \\
<* \mathrm{i} /\left[[\varnothing, \mathrm{s}, \mathrm{t}, \mathrm{NH}]_{[+\mathrm{ABS}+\mathrm{K}]}\right. \\
<* \mathrm{u} /\left[[\varnothing, \mathrm{s}, \mathrm{p}, \mathrm{t}, \mathrm{m}, \mathrm{n \#}]_{[+\mathrm{ABS}+\mathrm{K}]} \mathrm{s}_{[+\mathrm{OBL}+\mathrm{K}]}\right.\end{array}$ & $\begin{array}{l}\text { aka.A 'root' }(<* a k a r) \\
\text { sakat.A 'sick' }\left(<{ }^{*} \text { sakit }\right) \\
\text { kaja.A. 'wood' (<*kaju) }\end{array}$ \\
\hline -Cai(C) & $\begin{array}{l}<{ }^{*} \mathrm{i} /{ }_{[}[\varnothing, \mathrm{r}, \mathrm{h}, \mathrm{S}, \mathrm{k}, \mathrm{l} \#]_{[+\mathrm{OBL}+\mathrm{K}]} \\
<{ }^{*} \mathrm{u} / \_\mathrm{S \#} \\
{[+\mathrm{OBL}+\mathrm{K}]}\end{array}$ & $\begin{array}{l}\text { pilaih.O 'to choose' (<* pilih) } \\
\text { ayaih.O 'burnt' }(<* \text { *hayus })\end{array}$ \\
\hline$-\mathrm{Co}(\mathrm{C})$ & $<{ }^{*} \mathrm{u} /\left[[\mathrm{r}, \mathrm{h}, \mathrm{k}, \mathrm{\eta}, \mathrm{l} \#]_{[+\mathrm{ABS}+\mathrm{K}]}\right.$ & mussh.A 'enemy' (< *musuh) \\
\hline$-\mathrm{Ce}(\mathrm{C})$ & 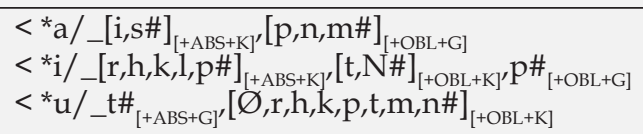 & $\begin{array}{l}\text { suye.A 'river' }\left(<{ }^{*} \text { suyai }\right) \\
\text { pike.A 'to think' }\left(<{ }^{*} \text { pikir }\right) \\
\text { lutek.O 'knee' (<*lutut) }\end{array}$ \\
\hline -Cea $(\mathrm{C})$ & $\begin{array}{l}<* \mathrm{i} /\left[[\varnothing, \mathrm{s}, \mathrm{t}, \mathrm{n}, \mathrm{n} \#]_{[+\mathrm{ABS}+\mathrm{G}]} 1 \#{ }_{[+\mathrm{OBL}+\mathrm{K}]}\right. \\
<* \mathrm{u} /\left[[\varnothing, \mathrm{s}, \mathrm{p}, \mathrm{m}, \mathrm{n \#}]_{[+\mathrm{ABS}+\mathrm{G}]}\right.\end{array}$ & $\begin{array}{l}\text { kancean.O'mousedeer' }(<* k a n c i l) \\
\text { batea.A 'stone' }(<* b a t u)\end{array}$ \\
\hline$-\mathrm{Ceu}(\mathrm{C})$ & $\begin{array}{l}<* a /[\varnothing, \mathrm{r}, \mathrm{u}, \mathrm{h} \#]_{[+\mathrm{OBL}+\mathrm{K}]} \\
<* \mathrm{u} /[\varnothing, \mathrm{h}, \mathrm{k}, \mathrm{r} \#]_{[+\mathrm{OBL}+\mathrm{K}]}\end{array}$ & $\begin{array}{l}\text { mateu.O 'eyes' (<* mata) } \\
\text { kaseu.O 'mattress' (< *kasur) }\end{array}$ \\
\hline$-\mathrm{C} \varepsilon(\mathrm{C})$ & $\begin{array}{l}<* \mathrm{a} /\left[[\mathrm{\eta}, \mathrm{l} \#]_{[+\mathrm{OBL}+\mathrm{G}]}\right. \\
<* \mathrm{u} / \_\mathrm{\eta} \#_{[+\mathrm{OBL}+\mathrm{K}]}\end{array}$ & 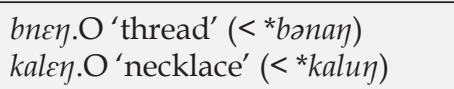 \\
\hline$-\mathrm{Ci}(\mathrm{C})$ & $\begin{array}{l}<* \mathrm{a} /[\mathrm{i}, \mathrm{s} \#]_{[+\mathrm{OBL}+\mathrm{G}]} \\
<* \mathrm{i} /\left[[\mathrm{r}, \mathrm{h}, \mathrm{k \#}]_{[+\mathrm{ABS}+\mathrm{G} /}[\mathrm{t}, \mathrm{n}, \mathrm{\eta} \#]_{[+\mathrm{OBL}+\mathrm{G}]} \mathrm{p} \#_{[+\mathrm{OBL}+\mathrm{K}]}\right. \\
<* \mathrm{u} /[\varnothing \varnothing, \mathrm{r}, \mathrm{h}, \mathrm{k}, \mathrm{p}, \mathrm{t}, \mathrm{t}, \mathrm{N \#}]_{[+\mathrm{OBL}+\mathrm{G}]}\end{array}$ & 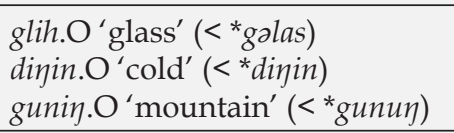 \\
\hline -Cia $(\mathrm{C})$ & $\begin{array}{l}<* a /\left[[r, i, u, h, s, k, p, t, l, N \#]_{[+A B S+G]}\right. \\
<* i / \_p \#{ }_{[+A B S+G]}\end{array}$ & $\begin{array}{l}\text { tajiam.A 'sharp' }(<* \text { tajam }) \\
\text { kdiap.A 'to blink' }(<* \text { kadip })\end{array}$ \\
\hline$-\mathrm{Co}(\mathrm{C})$ & $<* a / \_\varnothing \#_{[+A B S+K]}$ & mato.A 'eyes' (< * mata) \\
\hline$-\mathrm{Coa}(\mathrm{C})$ & $<* a / \_[p, t, l, N \#]_{[+\mathrm{ABS}+\mathrm{K}]}$ & ajoam.A 'chicken' (< *ajam) \\
\hline -Coi(C) & $<* a /\left[[i, S \#]_{[+O B L+K]}\right.$ & kapoih.O 'cotton' (< *kapas) \\
\hline$-\mathrm{Cu}(\mathrm{C})$ & $\begin{array}{l}<* \mathrm{a} /[\varnothing, \mathrm{r}, \mathrm{r}, \mathrm{h}, \mathrm{k \#}]_{[+\mathrm{OBL}+\mathrm{G}]} \\
<* \mathrm{u} /\left[[\mathrm{r}, \mathrm{h}, \mathrm{k}, \mathrm{h}, \mathrm{l},]_{[+\mathrm{ABS}+\mathrm{G}]} \mathrm{S \#}{ }_{[+\mathrm{OBL}+\mathrm{G}]}\right.\end{array}$ & $\begin{array}{l}\text { kudu.O 'horse' (<*kuda) } \\
\text { dapu.A 'kitchen' (<*dapur) }\end{array}$ \\
\hline$-\mathrm{Cua}(\mathrm{C})$ & $<* a / \_\varnothing \#_{[+A B S+G]}$ & kudua.A 'horse' (<*kuda) \\
\hline -Cui(C) & $<* \mathrm{i} /\left[[\varnothing, \mathrm{r}, \mathrm{h}, \mathrm{s}, \mathrm{k \#}]_{[+\mathrm{OBL}+\mathrm{G}]}\right.$ & sduih.O 'sad' (<*sadih) \\
\hline
\end{tabular}

Table 29. The rules of the innovation of the inherited root final ${ }^{*} \mathrm{CV}(\mathrm{C}) \#$.

\section{CONCLUDING REMARKS}

This is the first attempt at a description of the Semerap dialect of Kerinci. Like other Kerinci varieties, Semerap exhibits phrasal alternation, although the data are as yet too limited to detect clear patterns and possible differences with other varieties. The effect of non-prenasalized voiced stops was also examined. G-phonemes tend to trigger higher places of articulation, as is the case in Kerinci more generally.

The lexical data highlighted in this study were analysed from a historical perspective, calling attention to related phenomena in other Malayic varieties. The SMR phonology differs from that of other Kerinci dialects in its tolerance of velar voiceless stops in word-final position. Furthermore, the voiceless velar fricative /x/, a relatively rare phonemic in Malayic languages, is present in initial and medial position of inherited vocabulary. This study also 
encountered words which behave differently across Malay varieties. Adelaar (1992: 46) has already called attention to the unusual form of Malay kirim 'to send', one of the few non-borrowed attestations ending in -im. In SMR, it behaves oddly in the sense that it lacks phrasal alternation. Conceivably, anomalies in Kerinci phrasal alternation have something to say about the Malayic lexical development more generally.

In terms of historical development, this article has compared SMR with other Malayic varieties and with proto-Malayic reconstructions. The historical ${ }^{*} u$ and ${ }^{*} i$ are retained in SMR and do not undergo vowel lowering as in other varieties. The / / / in Standard Malay regularly corresponds to /a/ in Semerap. Together with Minangkabau, Inderagiri Hulu Malay, and Sambas Malay, SMR data support the reconstruction of proto-Malayic * $k a c i$ ? 'small' and *ambi? 'to take', rather than *kacil and *ambil. Finally, SMR lacks the historical infixes * $\mathrm{CorV}$ and ${ }^{*} \mathrm{C} ə \mathrm{lV}$ in some words and displays them in a smaller number in others. Future scholars might take these anomalies into account when examining other Malayic varieties. It is also hoped that more research on Kerinci dialects can add greater detail to the existing proto-Malayic reconstructions.

\section{AbBreviations}

$\begin{array}{ll}\text { A } & \text { absolute } \\ \text { ABS } & \text { absolute } \\ \text { ACT } & \text { active } \\ \text { C } & \text { consonant } \\ \text { DEM } & \text { demonstrative } \\ \text { G } & \text { g-word/phoneme } \\ \text { IHR } & \text { inderagiri hulu riau } \\ \text { K } & \text { k-word/phoneme } \\ \text { KK } & \text { koto keras } \\ \text { MKB } & \text { minangkabau } \\ \text { N } & \text { nasal consonant } \\ \text { O } & \text { oblique } \\ \text { OBL } & \text { oblique } \\ \text { PT } & \text { pondok tinggi } \\ \text { SBS } & \text { sambas } \\ \text { SM } & \text { standard malay } \\ \text { SMH } & \text { semerah } \\ \text { SMR } & \text { semerap } \\ \text { SP } & \text { sungai penuh } \\ \text { SSP } & \text { sonority sequencing principle } \\ \text { TPM } & \text { tanjung pauh mudik } \\ \text { V } & \text { vowel } \\ \text { 1SG } & \text { first person singular } \\ \text { 3SG.POSS } & \text { third person singular possesive } \\ & \end{array}$




\section{REFERENCES}

Abu Chacra, F. 2018. Arabic; An essential grammar. New York, NY: Routledge. [Second edition.]

Adelaar, K.A. 1992. Proto-Malayic; The reconstruction of its phonology and parts of its lexicon and morphology. Canberra: Department of Linguistics, Research School of Pacific Studies, Australian National University. [Revised edition of Adelaar 1985; Pacific Linguistics, Series C, 119.]

Anwar, J., A. Lana, A.H. Usman, S. Nikelas, Z. Amir, and M. Rusmali. 1984. Morfologi kata benda dan kata sifat bahasa Kerinci. Jakarta: Pusat Pembinaan dan Pengembangan Bahasa. Departemen Pendidikan dan Kebudayaan.

Butler, B.A. 2014. Deconstructing the Southeast Asian sesquisyllable; A gestural account. PhD thesis, Cornell University.

Ernanda. 2011. "On the loss of the phrasal alternation in Pondok Tinggi dialect of Kerinci; A stochastic optimality theory approach". MA thesis, Radboud University Nijmegen.

Ernanda. 2015. "Phrasal alternation in the Pondok Tinggi dialect of Kerinci; An intergenerational analysis", Wacana, Journal of the Humanities of Indonesia Vol. 16 No. 2: 355-382.

Ernanda. 2017. Phrasal alternation in Kerinci. PhD thesis, Leiden University. [LOT dissertation series.]

Isman, J. 1958. "Kerinchi phonology". MA thesis, Indiana University, Bloomington.

Matisoff, J. 1990. "Bulging monosyllables; Areal tendencies in Southeast Asian diachrony", in: K. Hall (ed.), Proceedings of the 16th Annual Meeting of the Berkeley Linguistics Society, pp. 543-559. Berkeley, CA: The Berkeley Linguistics Society.

McKinnon, T.A. 2011. The morphophonology and morphosyntax of Kerinci wordshape alternations. PhD thesis, Delaware University, Newark.

McKinnon, T., NFN Yanti, P. Cole, and G. Hermon. 2015. “Infixation and apophony in Malay; Description and developmental stages", Linguistik Indonesia, Jurnal Ilmiah Masyarakat Linguistik Indonesia 33(1).

Michaud, A. 2012." Monosyllabicization; Patterns of evolution in Asian languages", in: N. Nau, T. Stolz, and C. Stroh (eds), Monosyllables; From phonology to typology, pp. 115-130. Berlin: Akademie Verlag.

Nikelas, S., M. Rusmali, Z. Amir, N. Husin, and A.H. Usman. 1979. Struktur bahasa Kerinci. Jakarta: Pusat Pembinaan dan Pengembangan Bahasa. Departemen Pendidikan dan Kebudayaan. [Laporan penelitian oleh Fakultas Keguruan Sastra Seni. Padang: Institut Keguruan dan Ilmu Pendidikan.]

Nikelas, S., Z. Amir, M. Rusmali, A.H. Usman, and J. Anwar. 1981. Morfologi dan sintaksis bahasa Kerinci. Jakarta: Pusat Pembinaan dan Pengembangan Bahasa. Departemen Pendidikan dan Kebudayaan.

Prentice, D.J. and A.H. Usman. 1978. "Kerinci sound-changes and phonotactics", in: S.A. Wurm and L. Carrington (eds), Second International Conference on Austronesian Linguistics: Proceedings; Fascicle 1: Western Austronesian, pp. 
121-163. Canberra: Research School of Pacific Studies, The Australian National University. [Pacific Linguistics C-61.]

Reijn, E.O. van. 1974. "Some remarks on the dialects of North Kerintji; A link with the Mon-Khmer languages, Journal of the Malaysian Branch of the Royal Asiatic Society 31(2): 130-138.

Steinhauer, H. 2002. "More (on) Kerinci sound changes", in: K.A. Adelaar and R. Blust (eds), Between worlds; Linguistic papers in memory of David John Prentice, pp. 149-176. Canberra: Pacific Linguistics, Research School of Pacific and Asian Studies, Australian National University.

Steinhauer, H. 2018. "Sound-changes and loanwords in Sungai Penuh Kerinci", Wacana, Journal of the Humanities of Indonesia Vol. 19 No. 2: 375-407.

Steinhauer, H. and A.H. Usman. 1978. "Notes on the morphemics of Kerinci (Sumatra)", in: S.A. Wurm and L. Carrington (eds), Second International Conference on Austronesian Linguistics: Proceedings, Fascicle 1: Western Austronesian, pp. 483-502). Canberra: Research School of Pacific Studies, The Australian National University. [Pacific Linguistics C-61.]

Usman, A.H. 1976. Kamus umum Kerinci-Indonesia. Jakarta: Proyek Pengembangan Bahasa dan Sastra Indonesia dan Daerah, Pusat Pembinaan dan Pengembangan Bahasa. Departemen Pendidikan dan Kebudayaan.

Usman, A.H. 1988. Fonologi dan morfologi bahasa Kerinci dialek Sungai Penuh. $\mathrm{PhD}$ thesis, Universitas Indonesia.

Yanti, T. McKinnon, P. Cole, and G. Hermon. 2018. “The phonological basis of syntactic change in Kerinci", Oceanic Linguistics 57(2): 433-483.

Yasin, A. 1983. "Outline of Kerinci grammar with particular emphasis on WH-Questions". MA thesis, Ohio University.

Zuckermann, G. 2006. "Complement clause types in Israeli", in: R.M.W. Dixon and A.Y. Aikhenvald (eds), Complementation; A cross-linguistic typology, pp. 72-92. Oxford: Oxford University Press. 